\title{
STATE REGULATION AND SUPPORT OF TOURISM SERVICES IN THE RURAL REGIONS IN ACCORDANCE WITH EUROPEAN REQUIREMENTS
}

\author{
Yuriy Kyrylov ${ }^{1}$, Vadim Yarovoy ${ }^{2}$
}

\begin{abstract}
The objective of the article is to identify the problems of development of rural green tourism as an important direction of tourism activity in Ukraine and to substantiate their solution on the basis of state regulation and support. Methodology. In order to achieve an objective of the study, the general scientific and special methods were used: analysis and synthesis in the study of scientific principles of state regulation of services of rural green tourism; statistical analysis, comparison and generalization - in the study of the peculiarities of the organizational and economic mechanism of state regulation and support of rural green tourism services and the definition of modern aspects of the mechanisms of state regulation of rural green tourism; abstract-logical method for synthesis and formulation of conclusions and proposals. Results. The article reveals the challenges and problems of the development of rural population and rural areas in Ukraine. A special role in their solution of tourism activities in the form of rural green tourism was determined. Therefore, a considerable attention is paid to its state regulation and support. They are carried out in the form of regulatory and legislative support, monitoring systems, pricing services, taxation, etc. Practical importance. The obtained results can be used in practice by the state authorities, local authorities and self-government bodies, public organizations. The conducted study, conclusions drawn on their result, are the basis for: a further in-depth scientific study of the theory of public administration, development of recommendations for the improvement of conceptual provisions and measures for the implementation of an effective mechanism of state regulation and support of rural green tourism services. The scientific novelty of the results is that the theoretical foundations and conceptual approaches to improving the mechanisms of state regulation and support of rural green tourism services in Ukraine are substantiated.
\end{abstract}

Key words: tourism activity, rural green tourism, state regulation, support, rural territories, employment, population.

JEL Classification: Z32, M38, J21, P23

\section{Introduction}

The challenges posed by the modern economic system and its innovative development towards rural areas and agrarian enterprises make them look for interdependence and spatial patterns in the organization of vital functions of the population, processes of production and in its results. A particular attention is required to be paid to the level and quality of life of rural residents, employment opportunities and sources of income based on the use of available capital and other resources of agrarian formations, farms, and agrohomes. Tourist activity, first of all, rural green tourism as a direction of diversification of the economy of agrarian enterprises, is one of the ways of developing the village and reducing unemployment among the rural population. Therefore, their study has an important theoretical and practical significance.

Corresponding author:

${ }^{1}$ Kherson State Agrarian University, Ukraine.

E-mail: kirilov_ye@ukr.net

${ }^{2}$ Kherson State University, Ukraine.

E-mail: lawyer7522@gmail.com
Areas of development of services of rural green tourism in agrarian enterprises are concentrated in those areas where there are appropriate conditions for their operation. The state, based on the use of socio-economic and geopolitical levers, forms the environment, in which agrarian enterprises operate and interact. An important task for the development of rural green tourism on their basis is the regulation of the relevant regulatory framework, given the changing conditions of the environment. his should ensure the effective interaction of state and public structures for the successful development of tourism business in the rural areas.

\section{Challenges and problems of development of rural population and rural areas in Ukraine}

The legislative acts of Ukraine concerning services of rural green tourism of agrarian enterprises are 
the Constitution of Ukraine, the Laws of Ukraine "On Entrepreneurship" ("On Tourism”, 1995), "On Farmers" ("On Private Peasant Economy”, 2003), (Draft Law of Ukraine "On Rural Green Tourism”, 2007) and some other statutory and regulatory enactments. As the analysis showed, for the effective development and regulation of rural green tourism, the Law of Ukraine "On Rural Green Tourism" should be put into effect, the draft of which was adopted by the Verkhovna Rada Resolution No. 2179 as of November 16, 2004.

This Law defines the general legal, organizational, and socioeconomic principles of the implementation of the state policy of Ukraine in the field of rural green tourism and aims at ensuring the rights of citizens enshrined in the Constitution to rest, freedom of movement, healthcare, a safe environment for life and health, satisfaction of spiritual needs and other rights when making tourist trips. It establishes the principles of rational use of tourist resources and regulates relations related to the organization and implementation of rural green tourism in the country.

Specific features, reflected in the draft Law of Ukraine "On Rural Green Tourism", are changes in the specifics of licensing tourist activity; obligatory (optional) licensing of certain types of rural green tourism; regulation of issues related to the need for vocational training of subjects providing and carrying out activities in the field of rural green tourism; development of new types of contracts and clarification of their contents, which are concluded between the subject of this type of activity and the tourist. The draft proposes to develop standards that would regulate the requirements for providing rural green tourism services. These are requirements for premises, sanitary and hygienic conditions of accommodation, service personnel, food conditions, fire safety, registration of vacationer, civil liability of owners, property insurance.

The next regulatory document is the Decree of the President of Ukraine "On the Main Principles of Development of the Social Sphere of the Village" (2000), in which one of the means of development is the "development of auxiliary activity in the field of tourism (green tourism)" and giving priority "to the revival of national culture, customs, traditions and ceremonies, development of folk crafts", which is impossible without the development of tourist activity. Investigating the institutional environment for providing rural green tourism services showed that from the beginning of 2015 in Ukraine, there is no document that would describe short- and long-term prospects for the development of tourism activity in general and, therefore, rural green tourism in its composition.

The Cabinet of Ministers of Ukraine issued a decree "On Approval of the Concept of the State Target Program for the Development of Tourism and Resorts for the Period until 2022" on August 1, 2013. Practical use of this order has not been obtained, as of March 03,
2014 it was cancelled (by the decision of the Cabinet of Ministers of Ukraine, 2014). Given this situation, it is necessary to elaborate a scheme of the interaction of subjects for the implementation of a strategy supporting the development of entrepreneurship in the field of rural green tourism (Figure 1).

\section{The main directions of state support for rural green tourism services in Ukraine}

On the basis of the analysis of the legislation of Ukraine on rural green tourism, it is determined that the main directions of the state policy that will promote further effective development of this sphere are: improvement of regulatory legal principles of regulation of relations in this area of activity; definition of rural green tourism as an important link in Ukraine's tourism industry, encouraging domestic and foreign investment in this area and creating new jobs. It is also the development of foreign and inland rural green tourism, promoting its transformation into a cost-effective and competitive segment of the tourism industry.

It is about the creation of proper conditions for the development of services of rural green tourism, support for priority directions of tourist activity by simplification and harmonization of tax, currency, customs, border, visa, and other types of regulation. On the other hand, it is a comprehensive encouragement of Ukrainian citizens to participate in the development of the field of rural green tourism as a profitable part of tourism activity and an additional source of replenishment of personal incomes of citizens, local and state budgets. It is necessary to take into account the demand of consumers for certain types of services of rural green tourism when developing and approving national and local rural development programs and their location areas (Romaniuk, 2016). Areas of implementation of state support for rural green tourism are reflected in Figure 2.

The development of rural green tourism services by agrarian enterprises should be supported both at the state level and at the level of public organizations. Its main aspects are agro-resource, socio-economic, cultural and tourist and ecological and natural sciences. Therefore, in order to regulate the implementation of rural green tourism by agrarian formations, the interaction of state and public structures (non-governmental organizations) that are concerned with relevant industries or activities is required.

\section{Principles of state regulation of services of rural green tourism, which ensure the coherence of economic interests of enterprises, society, and the state}

Important features of state regulation of services of rural green tourism by agrarian enterprises are the principles that ensure the coherence of economic 


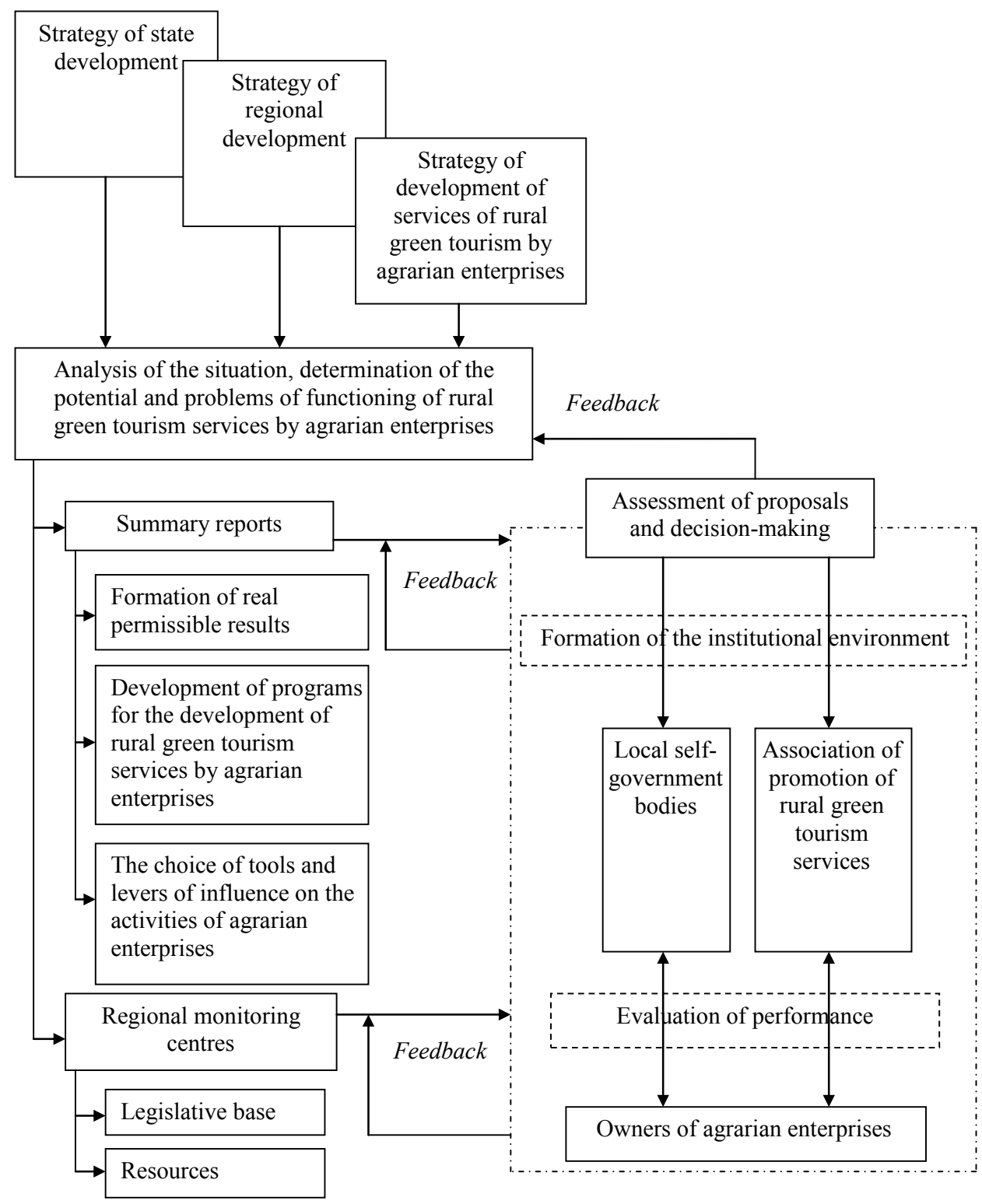

Figure 1. Management of the development of subjects of implementation of business strategy in the field of rural green tourism

interests of enterprises, society, and the state. Their observance should become a peculiar prevention for unsystematic, voluntaristic, and destructive intervention in the organizational and economic mechanism of management (Ihnatenko, 2010). Principles of state regulation, as well as management, are the result of a generalization of the inherent features, characteristic links, and constantly reproductive features, which become basic in the work of authorized subjects of state regulation.

The analysis showed that state regulation of services of rural green tourism by agrarian enterprises in Ukraine provides for the following principles to be observed: - definition of the priority directions of the state policy in the field of agrarian and tourist activity, development of rural territories;
- distribution of powers between executive authorities and local self-government bodies, rural communities; - consolidation of specific administrative functions within the competence of state regulatory bodies;

- systematic legal regulation of state regulation, the creation of its proper financial base;

- integrity, coherence, and effectiveness of mechanisms for the implementation of state policy.

The main principle of state regulation of rural green tourism services is the delegation of functions and powers of the central executive body in this area to public associations of rural masters provided that they comply with the requirements specified by law. Priority directions of state policy in the sphere of rendering services of rural green tourism to agrarian enterprises are also determined in the national program of tourism development in Ukraine. 


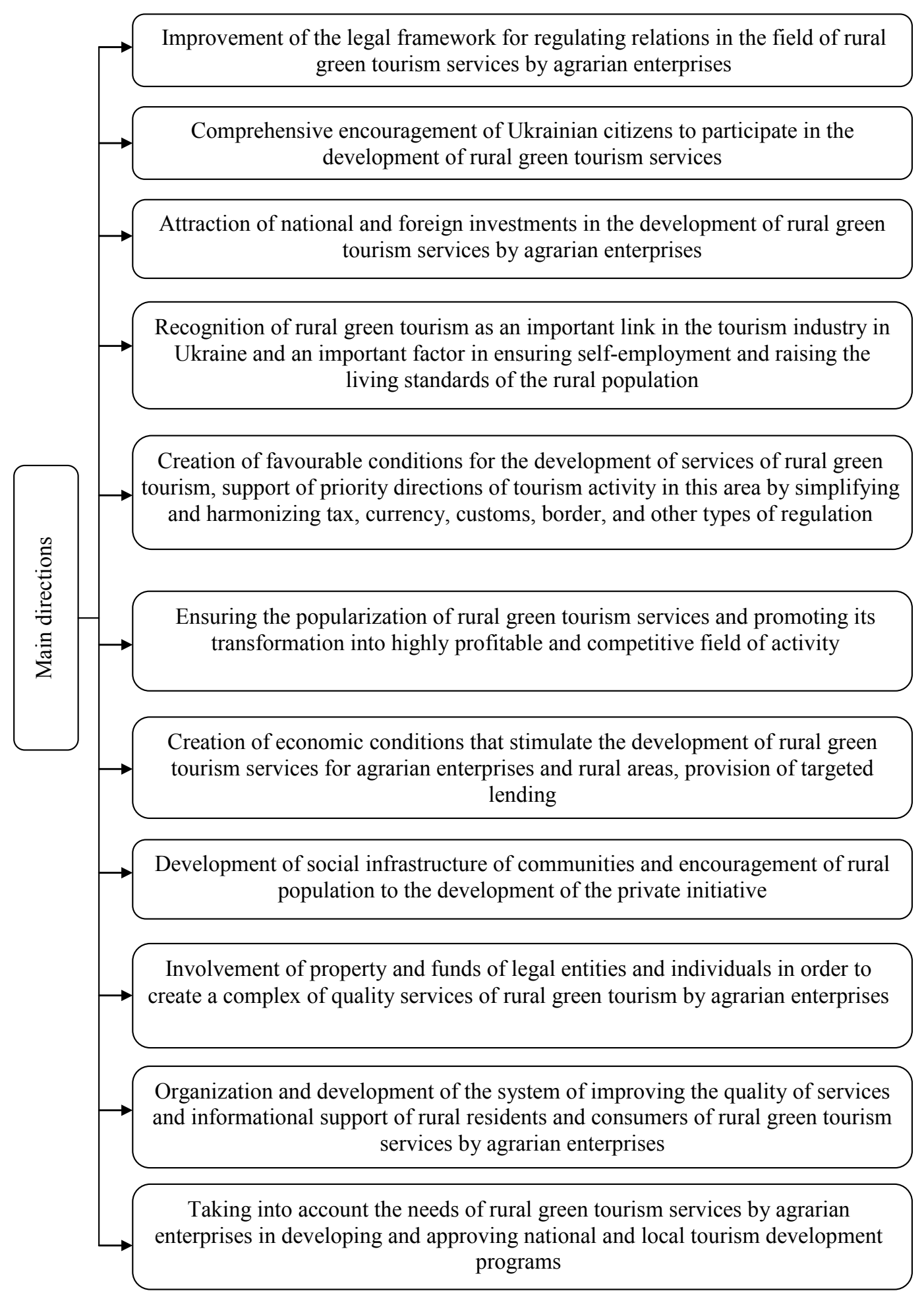

Figure 2. Main directions of state support of rural green tourism in Ukraine

Realization of the state policy in the field of rendering services of rural green tourism is carried out by: sending budget funds for the development and implementation of programs for its development, promotion, and advertising; normative regulation of relations in this sphere; delegation of authority to conduct categorization of rural green tourism objects by the association of villagers; organization and maintenance of statistical accounting and reporting of this kind of activity; organization and implementation of state control over observance of the legislation; assistance in the initiation, development, and implementation of international programs, as well as programs implemented through external investments, grants, etc. in this area; providing 
comprehensive assistance in creating the proper infrastructure (Marmul, Ihnatenko, Sarapina, 2016).

The main principles of state support for the provision of rural green tourism services by agrarian enterprises are equality of conditions, targeting separate agriculture and local communities, financing of projects in the field of rural green tourism services, rural infrastructure development, advertising, participation in exhibition and fairs, creation of folklore-cultural parks and parks of folk crafts (based on settlements that are carriers of a certain brand), the introduction of a comprehensive system of training for those employed in the green tourism and some others.

In order to support the development of rural green tourism services at the regional level, it is necessary to implement measures aimed at creating a profitable tourism industry that should meet the needs of domestic and international tourism taking into account the natural and climatic, recreational, socio-economic, historical and cultural potential of rural areas of the region and other capabilities.

As a result of the analysis of the Ukrainian legislation on the regulation of relations between business entities in the field of rendering services of rural green tourism, agrarian enterprises have been offered ways to regulate its legal framework (Rutynskyi, Zinko, 2008). This will enable to create a more favourable environment for the recreation of the urban population and activities in the field of rural green tourism. The reasons that deepen the existing problems of regulating its services by agrarian enterprises are the following:

1. Some local rural communities or local authorities overestimate the services of rural green tourism for a promising socio-economic development of their placement.

2. The degradation of the environment due to an increase in anthropogenic pressure on natural systems and the absence of mechanisms for its strict regulation and control in Ukraine.

3. Potentially higher indicators of crime and consumption of public goods through the levelling of the local cultural level, the transition to the standards of mass culture brought by tourists and the emergence of the need for a higher standard of living than is possible under the current employment in agricultural production.

4. Loss of the atmosphere of "rural life" by the village due to the excessive influences and crowds of tourists and their relaxed living in the countryside.

5. Loss of artistic uniqueness of products of folk craftsmen due to the increased demand for their products, and therefore - the transition of masters to the simplified small-scale production of their products with an emphasis on their souvenir attributes.

Owners of agrarian enterprises providing rural green tourism services need special loans for the development of rural green tourism on acceptable terms, taking into account the potential of the borrower and providing the banking institution with the lowest level of risk. In view of this, it is necessary to revise the specialized program "Village House" and reorient it to areas of financing from the state budget, not only for the construction of housing but also for the construction of the adjoining territory.

One of the priority tasks is the categorization of private estates in the field of rural green tourism services. It allows economic entities to report on the appropriate quality of housing conditions and the level of services, to establish a payment that corresponds to a certain category. It is such a marketing tool that will contribute to the promotion of certain objects of rural green tourism with the confirmation of the corresponding certificate (Kravchuk, 2008).

An in-depth study of tourists' requests in the field of rural green tourism services for agrarian enterprises and the offer of new tourist services to the market will be one of the means of diversifying the sources of rural incomes as components of integrated rural development and rural infrastructure, as well as one of the factors of the poverty reduction strategy in rural areas. Providing certain preferences, including tax, for economic entities in the field of rendering rural green tourism services and maximizing the simplification of accounting in them will only facilitate the effective regulation of this branch of entrepreneurship.

The identified features will ensure a higher level of development of services of rural green tourism by agrarian enterprises in a certain territory and will position it as an important means of stimulating and investing the socio-economic development of the village: promoting the development of rural infrastructure, complex rural development and rural infrastructure, creating new sources of income of rural population, as well as better provision of the rest of urban residents in the countryside; popularization of Ukrainian culture; dissemination of knowledge and information on the historical, natural, ethnographic features of Ukraine.

\section{Conclusions}

A comprehensive analysis of the peculiarities of state regulation of the provision of rural green tourism services by agrarian enterprises and rural masters and farms has shown that its development in the regions of Ukraine is becoming more extensive every year. It is one of the promising means of solving social issues concerning rural population employment, their socioeconomic development, the introduction of innovations and attraction of investments. The fulfilment of the tasks set for the regulation and development of rural green tourism will contribute to the qualitative development, organization, and management, as well as the attraction of investments in the tourism industry and the economy of Ukraine as a whole; the formation of its positive image in Europe and in the world. 


\section{References:}

The Verkhovna Rada of Ukraine (1995). Pro turyzm: Zakon Ukrayiny vid 15 veresnya 1995 roku № 324/95-VR [On Tourism: Law of Ukraine dated September 15, 1995 no. 324/95-VR]. Bulletin of the Verkhovna Rada of Ukraine, vol. 31, Art. 241.

The Verkhovna Rada of Ukraine (2003). Pro osobyste selyanske hospodarstvo: Zakon Ukrayiny vid 15 travnya 2003 roku № 742-IV [About the private peasant economy: Law of Ukraine dated May 15, 2003 no. 742 -IV]. Bulletin of the Verkhovna Rada of Ukraine, vol. 29, Art. 232.

Pro silskyy zelenyy turyzm: proekt Zakonu Ukrayiny vid 12.04.2007 r. № 3467 [About rural green tourism: the draft Law of Ukraine dated April 12, 2007, no. 3467]. Retrieved from: http://tourlib.net/zakon/pro_siltur.htm (accessed 21 June 2018)

Pro osnovni zasady rozvytku sotsialnoyi sfery sela: Ukaz Prezydenta Ukrayiny № 1356 vid 20.12.2000 r. [On the Basic Principles of the Development of the Social Sector of the Village: Decree of the President of Ukraine no. 1356 dated 20.12.2000]. Retrieved from: http://zakon3.rada.gov.ua/laws/show/1356/2000 (accessed 22 June 2018)

Pro skhvalennya Kontseptsiyi Derzhavnoyi tsilovoyi prohramy rozvytku turyzmu ta kurortiv na period do 2022 roku: Rozporyadzhennya [On Approval of the Concept of the State Target Program for the Development of Tourism and Resorts for the Period until 2022: Order]. Retrieved from: http://zakon3.rada.gov.ua/laws/show/638-2013$\%$ D $1 \% 80$ (accessed 21 June 2018)

Deyaki pytannya optymizatsiyi derzhavnykh tsilovykh prohram i natsionalnykh proektiv, ekonomiyi byudzhetnykh koshtiv ta vyznannya takymy, shcho vtratyly chynnist, deyakykh aktiv Kabinetu Ministriv Ukrayiny: Postanova Kabinetu Ministriv Ukrayiny [Some issues of optimization of state target programs and national projects, saving of budget funds and the recognition of certain acts of the Cabinet of Ministers of Ukraine: Resolution of the Cabinet of Ministers of Ukraine]. Retrieved from: http://zakon3.rada.gov.ua/laws/show/71-2014-\%D0\%BF (accessed 22 June 2018)

Romanyuk, I.A. (2016). Formuvannya korporatyvnoyi kultury ta dilovoyi reputatsiyi turystychnykh pidpryyemstv [Formation of corporate culture and business reputation of tourist enterprises]. Economy and management of culture, vol. 2, pp. 26-31.

Ihnatenko, M. M. (2010). Problemy ta perspektyvy rozvytku silskoho turyzmu v Ukrayini [Problems and prospects of development of rural tourism in Ukraine]. Scientific Bulletin of the Lviv National University of Veterinary Medicine and Biotechnology. SZ Gzhytsky. Series "Economic Sciences", vol. 1(43), no. 12, pp. 252-255.

Marmul, L. O., Ihnatenko, M. M., Sarapina, O. A. (2016). Sotsialno-ekonomichnyy potentsial silskykh terytoriy yak osnova rozvytku pidpryyemstv silskoho zelenoho turyzmu na zasadakh innovatsiynosti [Socio-economic potential of rural territories as the basis of development of enterprises of rural green tourism on the basis of innovation]. Economy and management of culture, vol. 2, pp. 32-38.

Rutinsky, M. Ya., Zinco, Yu. V. (2008). Silskyy turyzm [Rural tourism]. Kyiv: Knowledge. (in Ukrainian)

Kravchuk, I. (2008). Derzhavne rehulyuvannya rozvytku turyzmu: zarubizhnyy dosvid ta perspektyvy vprovadzhennya [State regulation of tourism development: foreign experience and prospects of implementation]. Visnyk of Lviv National University. Series "International Relations", vol. 24, pp. 134-141. 